\title{
The Interpretive Function: To Be or Not to Be, That is the Question
}

\author{
Heidi Agerbo, Centre for Lexicography, \\ School of Communication and Culture, Aarhus University, \\ Aarhus, Denmark(heap@cc.au.dk)
}

\begin{abstract}
Approximately a decade ago, it was suggested that a new function should be added to the lexicographical function theory: the interpretive function ${ }^{1}$. However, hardly any research has been conducted into this function, and though it was only suggested that this new function was relevant to incorporate into lexicographical theory, some scholars have since then assumed that this function exists ${ }^{2}$, including the author of this contribution. In Agerbo (2016), I present arguments supporting the incorporation of the interpretive function into the function theory and suggest how non-linguistic signs can be treated in specific dictionary articles. However, in the current article, due to the results of recent research, I argue that the interpretive function should not be considered an individual main function. The interpretive function, contrary to some of its definitions, is not connected to acting and therefore the only difference between reception and interpretation is that they work with different types of sign. However, the type of sign is not relevant for a function, or rather, it should not be a criterion for distinguishing between functions. The lemma selection for the communicative, cognitive as well as the operative functions could and should include linguistic as well as non-linguistic signs. Thus, theoretically, there is no reason to identify a fourth dictionary function as suggested by Tarp (2008), and practically, the development of modern technologies has diminished the distance in the treatment of different types of sign, making it easier for lexicographers to lemmatise non-linguistic signs. Concerning the point that non-linguistic signs are also worthy of lexicographical attention, my suggestion from 2016 still stands, the difference in this contribution being that the interpretive function is not considered an individual function.
\end{abstract}

Keywords: LEXICOGRAPHICAL FUNCTION THEORY, DICTIONARY FUNCTION, INTERPRETIVE FUNCTION, INFORMATION TOOLS, LINGUISTIC SIGN, NON-LINGUISTIC SIGN, ACTING

Opsomming: Die vertolkende funksie: Om te wees of nie te wees: dis die vraag. Omtrent ' $n$ dekade gelede is daar voorgestel dat ' $n$ nuwe funksie by die leksikografiese funksieteorie gevoeg moet word, naamlik die vertolkende funksie'. Min of geen navorsing is egter oor hierdie funksie gedoen nie, en hoewel daar slegs voorgestel is dat hierdie nuwe funksie relevant was en by die leksikografiese teorie ingewerk behoort te word, het sommige navorsers sedertdien aanvaar dat hierdie funksie bestaan², insluitende die outeur van hierdie bydrae. In Agerbo (2016) bied ek argumente ter ondersteuning van die opname van die vertolkende funksie in die funksieteorie en doen aan die hand hoe nietaalkundige tekens in spesifieke woordeboekartikels behandel kan word. Weens die bevindinge van onlangse navorsing argumenteer ek egter in die huidige 
artikel dat die vertolkende funksie nie beskou behoort te word as 'n aparte hooffunksie nie. Die vertolkende funksie, in teenstelling met sommige definisies, hou nie verband met toneelspel nie en dus is die enigste verskil tussen resepsie en interpretasie dat hulle werk met verskillende soorte tekens. Die soort teken is egter nie relevant vir 'n funksie nie, of eerder, dit behoort nie 'n maatstaf te wees om tussen funksies te onderskei nie. Die lemmaseleksie vir die kommunikatiewe, kognitiewe sowel as die operatiewe funksies kan en behoort sowel taalkundige as nietaalkundige tekens in te sluit. Teoreties is daar dus geen rede om ' $n$ vierde woordeboekfunksie te identifiseer nie, soos voorgestel deur Tarp (2008), en prakties het die ontwikkeling van moderne tegnologie die afstand in die behandeling van verskillende soorte tekens verklein, wat dit vir leksikograwe makliker maak om nietaalkundige tekens te lemmatiseer. Wat betref die punt dat nietaalkundige tekens ook leksikografiese aandag waardig is, bly my voorstel uit 2016 steeds geldig, met die verskil in hierdie bydrae dat die vertolkende funksie nie beskou word as 'n aparte funksie nie.

Sleutelwoorde: LEXIKOGRAFIESE FUNKSIETEORIE, WOORDEBOEKFUNKSIE, VERTOLKENDE FUNKSIE, INLIGTINGSHULPMIDDELS, TAALKUNDIGE TEKEN, NIETAALKUNDIGE TEKEN, TONEELSPEL

\section{The interpretive function in lexicographical literature and existing dic- tionaries}

Today, function theorists argue that there are four main functions: communicative, cognitive, operative and interpretive. The interpretive function in relation to the function theory was first mentioned briefly in Tarp (2008). In this article, Tarp writes that "[r]ecently, it has been discussed whether there is a fourth main user situation, the interpretive one, where the user needs to interpret signals and symbols in the surrounding world, but it is still too early to conclude anything in this respect" (2008: 11). Four years later, Bothma and Tarp state that "[t]he operative and interpretive situations have so far been scarcely studied by lexicography and there are only relatively few lexicographical works that cater for these situations" (2012: 91). Not much has been added to the description of the interpretive function since then despite the fact that it was first introduced in the above-mentioned article by Tarp in 2008, and despite the fact that at a symposium held at the Centre for Lexicography in Aarhus in 2008, it was said that the interpretive (and operative) situations "are starting to gain the attention of lexicographers and are therefore expected to be of interest in the near future" (Fernández and De Alba 2011: 307-308). This lack of attention has also been confirmed in an investigation carried out by this author of lexicographical literature in the period 2008-2016. In addition to this, no dictionary project has yet intentionally ${ }^{3}$ incorporated the interpretive function, though it could be argued that certain dictionaries of symbols can be ascribed such a function.

Apart from Tarp (2008), other texts commenting on this function often refer to the definition provided in this article, e.g. Bergenholtz, Bothma and Gouws (2015: 2), who write that when concerned with this function "[w]e need 
knowledge to be able to understand certain non-linguistic signs and to act accordingly (interpretative knowledge), cf. Tarp (2008)." Here, the authors specify that (1) the signs are non-linguistic, and (2) the user's intention is to find out how to act or react based on what the sign means or communicates. However, not all sources that mention the interpretive function or situation claim that a (re)action is involved, e.g. Tarp (2011: 65), who states that it is a situation where people need information in order "to receive help to interpret and understand non-textual and non-verbal phenomena or symbols." However, on the same page, Tarp (2011) also says that the interpretive situation is "when somebody needs an explanation (sometimes followed by recommendations to take action) in order to interpret a sound, a symbol or some similar non-linguistic and non-verbal sign" (emphasis added). This is also mentioned by e.g. Bergenholtz and Bothma (2011: 62), who point out that "[i]n interpretative situations the potential user has a need for assistance to interpret a non-language sign of some kind, e.g. a traffic sign. The right interpretation is normally needed to be able to act in the correct way," with the word "normally" indicating that it is not always the case that the situation involves a following action. Thus, the definition of the interpretive function is yet not clear nor agreed upon by function theorists.

Only one lexicographical project has so far described its dictionary as having an interpretive function: Leroyer (2010) and Leroyer and Høy (2013) describe the Oenolex Burgundy wine dictionary, for which they have planned an interpretive function. This dictionary is to be used when the user wants to understand a certain wine label. However, the function has yet not been incorporated into this project because the customer thinks that there are too many labels to work with and thus that it is an impossible or time-consuming task (Leroyer, personal communication). Though not turned into a real project, Leroyer (2009) suggests that for a tourist dictionary, it would be useful to incorporate an interpretive function so that "help [would] be given to interpret signs and signals of recommendation ensuring the positive outcome of tourist experience" (2009: 115), e.g. the star ranking system found in Michelin guides. Also only at a conceptual level, Agerbo (2016) suggests that for a sports dictionary, an interpretive function would be relevant as users may have problems understanding e.g. the hand signals or cards given by the referee to a player in a match and that the user therefore needs an information tool that explains what they mean and why the players act the way they do according to these signals. However, so far, no function-based dictionary project with an interpretive function has been produced and published.

Assuming for now that the interpretive function is an independent lexicographical function (although this will be questioned later), some existing information tools also have an interpretive function though this is not directly stated in the outside matter. A number of the investigated sports tools in Agerbo (2016) contained data - some in the central list and some as part of the outer text - that may be analysed as supporting an interpretive function. In The Dictionary of Sports (1949), referee signals are thematically collected in the 
back matter. Here, the images are supplemented by text explaining (1) what the referee is doing and (2) what his movement means. In Webster's Sports Dictionary (1976), the images are only supplemented by a short meaning explanation of the signal, not a description of the referee's movements. None of these two dictionaries apply cross-references, e.g. from time-out in the central list to the back matter or vice versa. In Sports: The Complete Visual Reference (2000), a number of flags used in motorsport are shown with explanations of their meanings. Interestingly, for the black flag with the orange disk, the explanation also tells the user how to react when this flag is shown, i.e. it includes an instruction. For archery, a description is given of the colour and sound signals ${ }^{4}$ used in archery to indicate when the archers can shoot. As in the example with the flags, the dictionary user is told what he can see (the colour) and how he should react to these signals. For American football and basketball, we yet again find examples of referee signals in the form of photos supplemented by the general meaning, e.g. "holding" (the verbal sign that is synonymous with the visual sign) and an elaborate text. Examples of such non-linguistic signs can also be found in dictionaries that are not connected to sports. For example, the Dictionary of Symbols (1991), which is divided into three sections (the symbol list in which the symbols are divided into thematic groups, the graphic index and the word index) has an interpretive function as its lemmata are symbols, not words made of alphabetical characters. The crowdsourced online Emoji Dictionary features a vast number of emojis, i.e. digital images (pictograms), used to express emotions or ideas, which are being incorporated more and more in people's everyday digital communication. A person reading an SMS may come across an emoji that she does not understand and will therefore access the Emoji dictionary in order to understand the meaning of this pictogram. The different emojis are structured thematically in broad categories, thus the user will have to search carefully to find the given emoji. In addition, general dictionaries may contain some non-linguistic signs, e.g. the signs $\%, \S$ and ? (these are non-linguistic signs, which are synonymous with the corresponding linguistic signs, e.g. \% is synonymous with the term percent sign), which for example are searchable and lemmatised in the online dictionary Den Danske Netordbog (En. The Danish Internet Dictionary).

It is easy to find dictionaries that apply non-linguistic signs in their explanations of certain lemmata, e.g. sports dictionaries and dictionaries of mathematics. However, these should not be confused with dictionaries that have an interpretive function. In the former case, non-linguistic signs are applied to describe linguistic signs, e.g. as in The Concise Oxford Dictionary of Mathematics (2013), whereas in the latter case, non-linguistic signs are explained with linguistic signs. Pictoral dictionaries may also be considered examples of interpretive dictionaries, but these incorporate images, which indeed are non-linguistic signs in the Peircean sense of the word, but most likely not the type of non-linguistic sign commented on by Tarp (2008) since these signs simply represent what they actually portray. 


\section{Defining the interpretive function}

In the investigated literature that comments on the interpretive function, the authors usually provide a very general definition of this function without further elaboration:

\begin{tabular}{|l|l|}
\hline Tarp (2008: 11) & $\begin{array}{l}\text { to interpret signals and symbols in the sur- } \\
\text { rounding world }\end{array}$ \\
\hline Leroyer (2009: 115) & to interpret signs and signals \\
\hline Bergenholtz and Bothma (2011: 62) & $\begin{array}{l}\text { to interpret a non-language sign of some kind, } \\
\text { e.g. a traffic sign }\end{array}$ \\
\hline Tarp (2011: 65) & $\begin{array}{l}\text { to interpret a sound, a symbol or some similar } \\
\text { non-linguistic and non-verbal sign }\end{array}$ \\
\hline Gallardo (2013: 87) & $\begin{array}{l}\text { to interpret non-linguistic signs such as traffic } \\
\text { signs, the explanatory tables of some manuals or } \\
\text { the graphics common to manuals of economics }\end{array}$ \\
\hline Bothma and Tarp (2014: 351) & $\begin{array}{l}\text { to interpret and understand a sign, signal, sym- } \\
\text { bol etc. }\end{array}$ \\
\hline Fuertes-Olivera and Tarp (2014: 51) & $\begin{array}{l}\text { to understand or interpret a specific phenome- } \\
\text { non, sign, symbol, text, etc. }\end{array}$ \\
\hline Agerbo (2016: 24) & $\begin{array}{l}\text { to interpret signals and symbols in the sur- } \\
\text { rounding world }\end{array}$ \\
\hline
\end{tabular}

Though these eight definitions all define the same function, they differ in two important points:

Question 1: Do you need to understand the given sign in order to carry out $a$ certain act?

Question 2: What types of sign are relevant for the interpretive function?

The following two subsections discuss these two points, i.e. (non)-acting and (non)-linguistic signs, in relation to the interpretive function.

\subsection{Acting or not acting}

Some of the above-mentioned definitions include acting as part of the interpretive function, others mention it as possible, but not mandatory, and some do not include it at all, i.e. there are three different perceptions of this function. If we argue that the user always or sometimes has to act or react, there is a certain overlap with the operative situation. In Bergenholtz, Bothma and Gouws (2015: 9), 
the process and results of operative and interpretive situations are described as follows (emphasis added):

- operative situations

- knowledge problem how to act $\rightarrow$

- information source $\rightarrow$

- act in the world after having got the needed information $\rightarrow$

- meta-reflections

- interpretive situations:

- acting problem reacting to a sign or a symbol $\rightarrow$

- information source $\rightarrow$

- acting or not acting in the world after having obtained the needed information $\rightarrow$

- meta-reflections

The emphasised parts show that the authors argue that operative situations involve a knowledge problem concerning how to act, whereas interpretive situations involve an acting problem on how to react to a sign (it must be assumed that the authors are talking about non-linguistic signs and not signs in general, i.e. linguistic as well as non-linguistic signs). This, however, is not described clearly enough and could instead be formulated in the following way:

- operative situations:

- knowledge problem concerning how to act $\rightarrow$

- information source $\rightarrow$

- understand given problem based on the information (instruction) $\rightarrow$

- act in the world, according to one's skills, after having received the needed information $\rightarrow$

- (meta-reflections)

- interpretive situations:

- knowledge problem concerning the meaning of a non-linguistic sign and possibly how to act according to it $\rightarrow$

- information source $\rightarrow$

- understand given problem based on the information (explanation + possibly instruction) $\rightarrow$

- act or not act in the world after having obtained the needed information $\rightarrow$

- (meta-reflections)

These process descriptions show that in the interpretive situation, the person first needs to understand a certain non-linguistic sign, and then he may have to act in a certain way according to the piece of information provided by the selected information tool. A question that arises from this is whether such 
interpretive situations which involve acting actually consist of one or two connected phases: (1) interpretation and (2) operation. For comparison, in the case of translation, Fuertes-Olivera and Tarp (2014) argue that from a lexicographical perspective, the translation process consists of three main phases and a number of sub-phases that among other things involve understanding, writing and revising a text. They write that "[i]n all these phases and sub-phases, the translators may experience various types of need which require specific types of lexicographical data as well as allowance for specific types of data access, in order to be satisfied" (2014: 67). In the same way, it could be argued that for interpretation, a user will also experience various types of need that require different types of data. However, there is an important difference between these two situations: the translation process always consists of three main phases, and the different translators may experience different problems in relation to these phases; but the interpretation process will not always be the same because the type of non-linguistic sign and the type of user will co-determine whether or not it is relevant for the user to act. For example, a chauffeur may have to understand a certain traffic signal because he needs to act according to it ${ }^{5}$; his passenger may also want to understand the signal, but he is not in a situation or role where he needs to act according to it. Thus, acting should therefore not be considered a part of the definition of the interpretive function. This means that the process description looks as follows:

- interpretive situations:

- knowledge problem concerning the meaning of a non-linguistic sign $\rightarrow$

- information source $\rightarrow$

- understand given problem based on the information (explanation) $\rightarrow$

- (meta-reflections)

The relation between acting and not acting may not only be a relevant discussion for interpretation, but also for reception though this is usually not part of the definition of this function. Bergenholtz, Bothma and Gouws (2015: 9) write that the communicative situation (e.g. reception and production) involves "acting in a text". However, this is a different meaning of the word act. When someone makes a lookup in an information tool, it could be argued that this will always be followed by some kind of action or acting, whether it is applying the information in the understanding of a text (reception) or when storing information in one's memory (cognition). But if we look at the definition of acting in relation to the operative function, Tarp (2008: 185) writes that operation is "where the user needs advice and instructions in order to perform any kind of mental or manual action, e.g. to operate a machine." Thus, the action that the person wants to perform requires that the person should be provided with advice and instructions, e.g. situations where a person wants to bake a cake (action) and uses a cookbook (instructions) in order to do so, or where a person wants to assemble a piece of furniture (action) and consults a user manual (instructions) in order to do so. Acting in a text and storing information in 
one's memory are thus not the types of action referred to in the definition of the operative function as these are not actions requiring advice or instructions; a reader does not get information on how to apply an explanation of a word in a given text. Thus, the acting part in the case of communication and cognition is not relevant for the actual purpose of the information search - and neither is it for interpretation.

\subsection{Linguistic and non-linguistic signs}

In the definitions presented earlier, either reference is made to non-linguistic signs, or the words signal, symbol and/or sign are mentioned. What the authors in general mean when they talk about the interpretive function is that people are confronted with and want to understand signs that are not verbal (related to language) and therefore are not usually treated in dictionaries; for instance, a graph in a maths book, the mating signal of a plant hopper, a red rash on one's body, a certain (cultural) gesture made by a native Spanish speaker to a native Danish speaker, or a referee signal in rugby. As these examples show, there are many different types of sign that could be considered in the discussion of the interpretive function. Inspired by Pierce's typology of signs, a list of these could look as the following 6 (notice that one sub-sign does not exclude another, e.g. a sign can be expressed with one's body and be connected to a certain culture, cf. the second bullet below):

- Linguistic signs (the ones traditionally treated in lexicography)

- Signs invented or produced and transmitted by humans consciously and creatively to convey a message (intentional/motivated)

- Using one's body to express meaning

- Using a machine, e.g. a traffic light, to express meaning

- Official, semi-official or intuitive signs

- Signs connected to a certain field; signs connected to a certain culture

- Tables, graphs etc. that require some background information to be understood

- Signs imitating what they represent, e.g. a drawing of a car or a flower

- Signs produced and transmitted by humans subconsciously or genetically (non-intentional/unmotivated) and which cannot always be ascribed a specific meaning

- Specific meaning: e.g. a reaction or behaviour characteristic of a specific person

- No specific meaning: e.g. a person making a burp

- Non-human produced signs (including animal sounds) attributed with meaning by humans, i.e. natural signs, e.g. a dark cloud in the sky indicating rain 
- Non-human produced signs that cannot be ascribed a specific meaning, e.g. the sound when a car drives too close to an item and gets scratched

Many of these signs are typically not incorporated in lexicographical tools, but why should they not be included if a user has an information problem related to one of these signs? However, a much more interesting question in the given context is the following: why should a distinction between linguistic and nonlinguistic signs result in different (main) functions; why are non-linguistic signs not relevant for cognitive tools and operative tools, and why should a distinction be made between reception and interpretation only in terms of the sign type? For example, a user may read a text in which a certain sign, e.g. a certain graph, is shown, and he wants to understand what it means - this corresponds to reception, though it involves the understanding of a non-linguistic sign; or a person may wish to know more about a certain non-linguistic sign as part of a school assignment - this corresponds to cognition, though, again, it concerns knowledge about a non-linguistic sign; or a person may want to know how to act according to a certain traffic sign - this corresponds to operation, though, as in the two previous examples, it concerns knowledge about a nonlinguistic sign. It therefore seems that a distinction based on linguistic sign versus non-linguistic sign is not decisive for the function and that the interpretive function should be rejected as a main function since the other functions would be able to cover both linguistic and non-linguistic signs.

A potential objection to this rejection of the interpretive function would be that not all types of non-linguistic sign can be connected to one of the three main functions, i.e. communication, cognition or operation, e.g. a dark cloud in the sky (which indicates that it may soon start raining). It is definitely possible to imagine an information tool in which different types of weather signs are explained, e.g. what it means when the temperature suddenly drops or when you can sense a certain smell in the air; thus, these signs are assumingly relevant for reception (communication). Nevertheless, in the traditional understanding of communication, a message (sign) would involve a sender and a receiver. Yet, the determining factor for reception is that a person sees a sign that he wants to understand, i.e. the relevant factors are the receiver and his information need, not the sender. For some signs, we know who the sender is (a woman uses the word "palindrome" in a conversation with a man and he does not know what this word means); for others, we do not know who it is (a person has put up a sign in a park which many people read daily, but without them knowing who the sender is); for a third category, a person is not aware that he is making/sending a sign to someone (a man is yawning unintentionally because he is bored listening to his wife talking, and this is seen by a person sitting next to the couple); and for a fourth category, there is no particular sender (a person gets a rash and wants to understand what it means). In the case of text production and translation, only signs made by human beings are lexicographically relevant, but for reception - and also cognition - all types of sign are (or could potentially) be lexicographically relevant. 
3. Future tools: user situations and needs related to search options and signs

Until now, general dictionaries have mainly been concerned with linguistic signs, and it is only some specialized dictionaries that to some extent incorporate non-linguistic signs though the search methods and presentations are primitive. For example, instead of grouping these non-linguistic signs thematically (cf. Dictionary of Symbols), it would be more useful for the user if he could, in an e-tool, either search for a non-linguistic sign using an actual photo or by typing in keywords describing the sign he is looking for, in this way making the software search in an explanation field connected to the relevant lemma. Below, the possible search options and user needs connected to specific nonlinguistic and their related linguistic lemmata are suggested for future reference works.

\subsection{Yellow card and (linguistic sign and non-linguistic sign)}

- Reception: You want to know what the term yellow card or the photo of a yellow card means so you search either with the linguistic or the non-linguistic sign in the search field

- Production: You want to know how to write the term in the plural so you search with the linguistic sign in the search field

- Translation: You want to know what the term means (its equivalent) in a different language so you search with the linguistic sign in the search field

- Cognition: You want to know more about yellow cards in sports in general so you search with either the linguistic or the non-linguistic sign in the search field

- Operation: You want to know how/when to give someone a yellow card so you search with either the linguistic or the non-linguistic sign in the search field (NB: this is only relevant for referees)

\subsection{A specific bird sound (non-linguistic sign)}

- Reception: You want to know what robins communicate to each other so you insert the non-linguistic sign (your own recording of robins communicating) in the search field (NB: whether this is plausible is questionable)

- Cognition: You want to know what kind of bird makes a specific sound so you insert the non-linguistic sign (your own recording of an unknown bird sound) in the search field

- Cognition: You want to know as much as you can about robins for a certain purpose so you insert the non-linguistic sign (a recording of a robin singing, either your own or from some other source) in the search field 
3.3 The emoji called face with tears of joy and non-linguistic sign)

(linguistic sign and

- Reception: You want to know what this emoji means so you search either with the linguistic or the non-linguistic sign in the search field (NB: for the linguistic sign, it is a problem that there is no official name for each emoji)

- Production: You want to know how you write a text message using this non-linguistic sign so you search with the non-linguistic sign in the search field; or you want to know how to write the term (the linguistic sign) in the plural (is it faces with tears of joy or face with tears of joys?)

- Cognition: You want to know as much as you can about this emoji so you search either with the linguistic or the non-linguistic sign in the search field

\subsection{A specific occurrence of a rash: (non-linguistic sign)}

- Cognition: You want to know what caused the rash (and possibly how to get rid of it) so you search with the non-linguistic sign (a photo of the rash) or with keywords connected with Boolean operators (e.g. rash + back + "red dots")

- Operation: You want to know how to get rid of the rash so you search either with the photo or (if you know what caused it) the name of the "thing" or phenomenon that caused the rash (e.g. tree nut allergy)

3.5 The traffic sign called the full stop sign and non-linguistic sign)

(linguistic sign and

- Reception: You want to know what the term full stop sign or the photo of this traffic sign means so you search either with the linguistic or the nonlinguistic sign in the search field

- Production: You want to know how to write the term in the plural so you search with the linguistic sign in the search field

- Translation: You want to know what the term means in a different language so you search with the linguistic sign; or you want to know if this traffic sign looks different in a different culture so you search with the non-linguistic sign

- Cognition: You want to know more about this traffic sign so you search either with the linguistic or the non-linguistic sign in the search field

Not all of the resulting dictionary articles would occur in a general dictionary. For example, the operative article for yellow card could occur in a set of rules or a referee's handbook structured according to lexicographical principles. Bird sounds could occur in a specialized cognitive e-tool for ornithologists, which would relate different sounds to different birds and explain when, for how 
long, where, etc. they sing. The dictionary article of a rash could occur in an online medical handbook for specialists or for laymen who want to know what it is a symptom of and how (if possible) they can treat it. Images of traffic signs could occur in general dictionaries as lemmata, but future reference tools might also be integrated into car computers in order to register traffic signs on the road so the computer could inform the driver about the meaning of the given sign.

As these examples show, though some of the future information tools may resemble traditional dictionaries, many others will be innovative and therefore unique in their design and search options. This is not only due to the integration of computer and information technologies in lexicography, but also to the formulation of an independent lexicographical theory based upon dictionary functions, cf. Nielsen (2013: 356), who states that "[w]hat objects people will regard as dictionaries may change, however, owing to a range of factors, including the types of need identified, the media available, and the types of help provided." Hanks (2012: 81) mentions that "[n]o doubt it would be technically straightforward enough to include film clips of typical elephant behaviour, including the sound of elephants trumpeting. Perhaps the technology is not far away by which we shall be able to sit at our computer and touch a simulation of an elephant's skin or smell a bull elephant in musth." Moreover, Lew (2010: 299) writes, "[p]erhaps a radical solution becomes available in the near future in the form of projector glasses, which would display an image on the inside of their lenses for the wearer to view, thus utilizing a large fraction of the human field of vision. In the not-so-near future, 3D holographic projectors may become a possibility ${ }^{7}$, but for the moment this is the stuff of science fiction rather than science." Though these suggestions may seem unrealistic at the moment, we, lexicographers, should not be afraid of suggesting such innovative moves as this is the only way to move forward. Kwary (2012), for example, suggests that calculators should be incorporated into a reception e-dictionary of economics, and he also shows that the four components tooltip, speech recognition, auto-summarize and definition-finder could be incorporated into a similar type of dictionary. Of course, as argued by Nielsen (2013: 370), the lexicographical platform should be supported by two pillars: a practical one (i.e. available technical features), and a theoretical one, i.e. needs-adapted data presentation. Thus, it is not simply a matter of using new technologies, but applying these in a way that the user can easily extract the information he needs to solve his information problem.

\section{Some characteristics of future lexicographical information tools}

- New types of information needs (e.g. needs for acting according to or understanding non-verbal signs) can be satisfied with these tools

- New types of data (e.g. videos and smells) are incorporated

- New search options (e.g. searches made with sounds and images in addition to words and letters) are available 
- New ways of structuring and presenting data in order to ensure a more dynamic approach to the incorporation of data

\section{The interpretive function: not to be}

A dictionary function should be based on a certain type of information need that a person experiences in a specific type of situation, not on whether the problem involves a linguistic or a non-linguistic sign. The main reason for having called the interpretive function an independent dictionary function has probably been that lexicographers have not been used to lemmatising non-linguistic signs in lexicographical information tools, and therefore it may appear as a different situation when we come across such signs. However, the basic function is the same whether we want to, for example, understand what a linguistic sign or a non-linguistic sign means or how to react to a given type of sign. Therefore, the function theory does not operate with four main functions, but three: communicative, cognitive and operative. The communicative function has been well-researched, which has resulted in a further division into the following four subfunctions: reception, production, translation and revision/ marking. Though cognition has been considered a main function together with the communicative function since the first mention of the function theory in the beginning of the 1990s, it is still unclear what it actually covers. We may distinguish between punctual information problems (e.g. when was Napoleon born?) and general information problems (e.g. I want to know as much as is relevant in my situation about the Napoleonic Wars), but further subfunctions have yet not been identified. The operative function was first mentioned in lexicographical literature 10 years ago, but surprisingly, no research has yet been conducted on this function, though see Agerbo (in review). For all of these three main functions, both non-linguistic and linguistic signs could be relevant. Incorporating non-linguistic signs in paper format is problematic since these cannot be incorporated in the same way as linguistic signs; but with the computer technologies that are available today and probably will be available in the near future, it will become much easier to incorporate such non-linguistic lemmata in lexicographical e-tools. It is a matter of using the technical tools that are available and not being afraid of thinking out of the box when trying to satisfy the needs of the intended dictionary users.

\section{Endnotes}

1. In some articles, this function is called interpretative, in others interpretive. I choose to apply the term interpretive function in this article.

2. Of course, the word exists should not be understood as if there is some kind of objective reality in which this function can be found; it means that it is relevant to construct such a category to work with in lexicographical theory. 
3. In this context, the word intentionally means that the producer directly writes that the given tool has an interpretive function or that the producer in some other way makes it clear that the purpose of the tool is to help the user understand a non-linguistic sign (this would typically be mentioned in the introduction, i.e. the outside matter).

4. Of course, sounds cannot be directly represented in a paper dictionary, only by description, but this would be possible in an electronic dictionary.

5. Kwary (2012: 32) makes a distinction between real needs and ancillary needs of which the latter may occur during dictionary consultation. This could be connected to the given case in which a person may look up in an information tool to understand the meaning of a certain traffic signal, and based on this, he also wants to know how to act according to the sign.

6. It may be that other types of sign should be added to this list.

7. Nielsen (2013: 368) makes this same suggestion, "[i]t is possible that online dictionaries may present data in three-dimensional form, including holograms."

\section{References}

\section{Dictionaries}

Bergenholtz, H. (Ed.). 2017. Den Danske Netordbog. Odense: ordbogen.com.

Clapham, C. and J. Nicholson. 2013. The Concise Oxford Dictionary of Mathematics. Fifth edition. Oxford: Oxford University Press.

Copeland, R. 1976. Webster's Sports Dictionary. Springfield, Mass.: G. \& C. Merriam. Cummings, P. (Ed.). 1949. The Dictionary of Sports. New York: A.S. Barnes \& Company. Emoji Dictionary = https://emojidictionary.emojifoundation.com.

Fortin, F. 2000. Sports: The Complete Visual Reference. Willowdale, Ont.: Firefly Books.

Liungman, C.G. 1991. Dictionary of Symbols. New York: Norton.

\section{Other Literature}

Agerbo, H. 2016. The Incorporation of Specialised Data in Lexicographical Meaning Explanations: A Discussion Based on Sports and Fitness Terms. Lexikos 26: 1-35.

Agerbo, H. In review. Monofunctional and Polyfunctional Information Tools with an Operative Function.

Bergenholtz, H. and T.J.D. Bothma. 2011. Needs-adapted Data Presentation in e-Information Tools. Lexikos 21: 53-77.

Bergenholtz, H., T.J.D. Bothma and R.H. Gouws. 2015. Phases and Steps in the Access to Data in Information Tools. Lexikos 25: 1-30.

Bothma, T.J.D. and S. Tarp. 2012. Lexicography and the Relevance Criterion. Lexikos 22: 86-108.

Bothma, T.J.D. and S. Tarp. 2014. Why Relevance Theory is Relevant for Lexicography. Lexicographica $30: 350-378$.

Fernández, E.S. and B.P.C. de Alba. 2011. Conclusions: Ten Key Issues in e-Lexicography for the Future. Fuertes-Olivera, P.A. and H. Bergenholtz (Eds.). 2011. e-Lexicography: The Internet, Digital Initiatives and Lexicography: 305-311. London: Continuum.

Fuertes-Olivera, P.A. and S. Tarp. 2014. Theory and Practice of Specialised Online Dictionaries: Lexicography versus Terminography. Berlin/Boston: De Gruyter. 
Gallardo, Á.R. 2013. The Function Theory and its Application on Manuals of Economics. Hermes. Journal of Language and Communication in Business 50: 83-95.

Hanks, P. 2012. Corpus Evidence and Electronic Lexicography. Granger, S. and M. Paquot (Eds.). 2012. Electronic Lexicography: 57-82. Oxford: Oxford University Press.

Kwary, D.A. 2012. Adaptive Hypermedia and User-oriented Data for Online Dictionaries: A Case Study on an English Dictionary of Finance for Indonesian Students. International Journal of Lexicography 25(1): 30-49.

Leroyer, P. 2009. Balancing the Tools: The Functional Transformation of Lexicographical Tools for Tourists. Nielsen, S. and S. Tarp (Eds.). 2009. Lexicography in the 21st Century: In Honour of Henning Bergenholtz: 103-122. Amsterdam/Philadelphia: John Benjamins Publishing.

Leroyer, P. 2010. Ej blot til lyst — Konsultation og navigation i leksikografiske informationsværktøjer. Nordiske studier i leksikografi 10: 313-328.

Leroyer, P. and A. Høy. 2013. Vinsmagningsordbogen Oenolex Bourgogne. En Milepæl i Pragmatisk Fagleksikografi. Nordiske Studier i Leksikografi 12: 287-302.

Tarp, S. 2008. Revival of a Dusty Old Profession. Hermes. Journal of Language and Communication in Business 41: 175-188.

Tarp, S. 2011. Lexicographical and Other e-Tools for Consultation Purposes: Towards the Individualization of Needs Satisfaction. Fuertes-Olivera, P.A. and H. Bergenholtz (Eds.). 2011. e-Lexicography: The Internet, Digital Initiatives and Lexicography: 54-70. London/New York: Continuum. 